\title{
The Appealability of Class Action Settlements by Unnamed Parties
}

\author{
Timothy A. Duffy $\dagger$
}

Class action suits are unique in that they necessarily determine the rights and duties of absent parties. While this mechanism generally allows for more uniform and efficient adjudications than would otherwise be possible, the fact that unnamed class members must rely on class representatives to protect their interests necessitates a host of procedural safeguards for the parties as well as a heightened role for the court. ${ }^{1}$ The rights of unnamed class members are particularly at risk when a class action is settled prior to an entry of a judgment on the merits. Because unnamed parties' rights are easily compromised in such situations, Federal Rule of Civil Procedure $23(\mathrm{e})^{2}$ does not permit the named representatives to settle a class action without court approval and notice to all class members. ${ }^{3}$ The court must also provide a reasonable opportunity for dissatisfied class members to present their objections to the court. ${ }^{4}$

Courts dispute, however, whether unnamed parties have standing to appeal an order approving a class action settlement. ${ }^{5}$

$\dagger$ B.A. 1991, The University of Colorado at Colorado Springs; J.D. Candidate 1994, The University of Chicago.

1 "[T] hese individuals are akin to "wards of the court." "Zients $v$ LaMorte, 459 F2d 628, 630 (2d Cir 1972), quoting Zechariah Chafee, Jr., Some Problems of Equity 292 (Michigan, 1950). For a general discussion of the peculiar issues surrounding the status of unnamed parties, see Herbert B. Newberg, 1 Newberg on Class Actions $\$ \S 1.07,1.08$ (McGraw-Hill, 2d ed 1985).

2 "A class action shall not be dismissed or compromised without the approval of the court, and notice of the proposed dismissal or compromise shall be given to all members of the class in such manner as the court directs."

${ }^{3}$ See generally Chester B. McLaughlin, Capacity of Plaintiff-Stockholder to Terminate a Stockholder's Suit, 46 Yale L J 421 (1936) (calling for the judicial supervision of settlements to ensure fairness while maintaining judicial economy). A reference to McLaughlin's article comprises the whole of the advisory committee's note to part (c) of the pre-1966 version of FRCP 23, which is part (e) of the current rule.

- See Greenfield v Villager Industries, Inc., 483 F2d 824, 832-33 (3d Cir 1973).

- Note that an order approving a settlement is also referred to as a consent decree if the settlement provides for some sort of injunctive relief. There is no difference, however, from the perspective of an unnamed class member seeking to appeal the order. 
Some courts allow such appeals in all cases, ${ }^{6}$ others require the class member seeking to appeal to have objected below, ${ }^{7}$ and still other courts require an unnamed class member formally to intervene in the action to secure the right to appellate review. ${ }^{8}$ The inconsistency of these approaches leaves unnamed class members without a clear sense of their rights and thus calls for the adoption of a uniform rule.

Section I of this Comment summarizes the leading cases and outlines the current state of the law. Section II then analyzes the issue from three perspectives: history, equity, and judicial efficiency. Each of these perspectives reflects different concerns, and thus their conclusions vary in scope. Nevertheless, one of the approaches accommodates all of these concerns reasonably well. As this Comment argues, an unnamed class member should be allowed to appeal an order approving a settlement in a class action suit as long as that class member has objected below. This solution is historically sound, reasonably equitable, and ultimately more practical than either of the other two approaches courts have adopted.

\section{The State of the Law: Three Positions}

Courts have developed three positions in response to the issue of whether an unnamed class member has standing to appeal an order approving a class action settlement. The most permissive position allows unnamed class members to appeal a settlement unconditionally. Under a second, slightly more restrictive, approach, unnamed class members may appeal as long as they have objected to the settlement in the court below. Third, some jurisdictions shift the focus of this question by requiring unnamed class members to intervene in the action-thus actually becoming named parties-before appealing. 1971).

- See, for example, Ace Heating \& Plumbing Co. $v$ Crane Co., 453 F2d 30, 33 (3d Cir

' See, for example, Research Corp. $v$ Asgrow Seed Co., 425 F2d 1059, 1060-61 (7th Cir 1970).

See, for example, Croyden Associates v Alleco, Inc., 969 F2d 675, 680 (8th Cir 1992), cert denied as Weinberg Foundation, Inc. v Croyden Associates, 113 S Ct 1251 (1993). 


\section{A. Unnamed Class Members May Always Appeal}

Some courts have simply held that any class member may appeal an order approving a settlement in a class action..$^{9}$ In Ace Heating \& Plumbing $v$ Crane Co., the Third Circuit found that unnamed class members had standing to appeal a settlement in a nationwide antitrust case, even though the appellants had not objected below and even could have excluded themselves from the settlement. ${ }^{10}$ The court noted that "ordinarily, aggrieved class members may appeal any final order of a district court in proceedings held pursuant to Rule 23."11 Observing that the right to be excluded is often illusory where class members' claims would be too small to litigate unless aggregated, the court concluded that a right to appellate review was necessary to guard against unfair settlements. ${ }^{12}$

The current status of Ace Heating is somewhat uncertain. Subsequent cases in the Third Circuit have all involved appellants who had objected below. ${ }^{13}$ These decisions have therefore relied on other precedent for the proposition that unnamed class members who object in the court below may appeal an order approving a settlement. ${ }^{14}$ In addition, at least one court has sought to limit the scope of the holding in Ace Heating, characterizing it as an exception rather than a generally applicable rule. ${ }^{15}$

In Marshall $v$ Holiday Magic, Inc., the Ninth Circuit followed Ace Heating, holding that unnamed class members have standing to appeal an order approving a settlement simply because their

- Ace Heating, 453 F2d at 33; Marshall v Holiday Magic, Inc., 550 F2d 1173, 1176 (9th Cir 1977); In Re Equity Funding Corp. of America Securities Litig., 603 F2d 1353, 1361 (9th Cir 1979).

10453 F2d at 32 .

11 Id.

12 Id at 33.

13 See Bell Atlantic Corp. v Bolger, 2 F3d 1304 (3d Cir 1993), reasoning from Ace Heating that an objecting class member has standing on appeal, but not providing a clear answer to the question in the context of class members who do not object. See also Greenfield $v$ Villager Industries, Inc., 483 F2d 824, 829 (3d Cir 1973); Tate v Werner, 68 FRD 513, 519 (E D Pa 1975); Webcor Electronics v Whiting, 101 FRD 461, 465 n 11 (D Del 1984).

14 See, for example, Greenfield, 483 F2d at 829, citing Cohen $v$ Young, 127 F2d 721 (6th Cir 1942).

${ }^{13}$ In re Four Seasons Securities Laws Litig., 502 F2d 834, 844 n 12 (10th Cir 1974). The reasoning of Four Seasons is suspect for two reasons. First, Four Seasons erroneously cites Ace Heating as having considered Research Corp. $v$ Asgrow Seed Co., 425 F2d 1059 (7th Cir 1970). 502 F2d at 844. However, Ace Heating does not contain any citation to Asgrow. Second, Four Seasons involved an appellant who sought relief from a judgment under FRCP 60(b), not an appeal of the merits of an order approving a settlement. Id. 
rights were being adjudicated. ${ }^{16}$ "As members of the class," wrote the Marshall court, "[unnamed class members'] legal rights are affected by the settlement and they have standing to sue."17 But the subsequent experience of the Ninth Circuit has been similar to that of the Third: courts have more commonly confronted cases in which the appellant has objected below and have therefore tended to formulate their decisions more narrowly. ${ }^{18}$

Nevertheless, Ace Heating and Marshall represent a viable response to the standing issue. They raise the simple but powerful "general proposition" that since unnamed class members' rights are at stake, they should be allowed to obtain appellate review of class action settlements. ${ }^{19}$ Moreover, the Ace Heating/Marshall approach recognizes the practical limitations faced by class members in any class action that aggregates a number of small claims. ${ }^{20}$ The supposed "options" of unnamed class members-which usually boil down to maintaining a separate action-are often "equally unpalatable alternatives" that essentially foreclose the parties' claims. $^{21}$

B. Unnamed Class Members May Appeal If They Have Objected Below

The earliest case to address the specific question of whether an unnamed class member had standing to appeal an order approving a settlement was Cohen $v$ Young. ${ }^{22}$ Cohen involved a shareholder derivative suit in which an unnamed class member received notice of a proposed settlement, appeared at a hearing to oppose the settlement, and also moved to intervene in the action. ${ }^{23}$ Though the unnamed class member did not contest the denial of his motion to intervene, he did appeal the lower court's order approving the settlement. ${ }^{24}$ The Sixth Circuit held that a class member who had objected to a proposed settlement was "entitled as of

${ }_{16}^{16} 550$ F2d 1173, 1176 (9th Cir 1977). Accord Equity Funding, 603 F2d at 1361.

${ }^{17} 550$ F2d at 1176 (citing Ace Heating).

18 Dosier v Miami Valley Broadcasting Corp., 656 F2d 1295, 1299 (9th Cir 1981); In re Cement Antitrust Litig., 688 F2d 1297, 1309 (9th Cir 1982) (citing Ace Heating for the proposition that class members who do object to the settlement may appeal); Silber $v$ Mabon, 957 F2d 697, 700 (9th Cir 1992).

19 Ace Heating, 453 F2d at 32; Marshall, 550 F2d at 1176.

${ }^{20}$ Ace Heating, 453 F2d at 33; Marshall, 550 F2d at 1176.

${ }^{21}$ Ace Heating, 453 F2d at 33.

${ }_{22} 127$ F2d 721 (6th Cir 1942).

${ }^{23}$ Id at 723.

24 Id at 724. 
right to prosecute the appeal."2s The court analogized the position of the unnamed class member to that of a defendant "who is summoned by process of court and after an adverse ruling has the right to appeal.".26

The Seventh Circuit provided the other lead case in support of this position. In Research Corp. $v$ Asgrow Seed Co., members of a defendant class appealed an order approving a settlement in an antitrust case. ${ }^{27}$ The appellants were not named parties, nor had they objected at the settlement hearing. ${ }^{28}$ The court dismissed the appeal and held that if "a class member intervenes or even appears in response to a notice pursuant to [FRCP] 23(e) and objects to the dismissal or compromise, he has a right to appeal from an adverse final judgment. . . . However, . . . a person in disagreement with the terms of a settlement must take, at least, these minimal steps to preserve his right to appeal."28 Cohen had held that an objection below was sufficient to confer standing on appeal; Asgrow made objection a necessary condition as well.

Some courts have read a discrepancy in Asgrow's language as requiring not only an objection, but also intervention by the unnamed class member seeking to appeal. ${ }^{30}$ In a footnote, the Asgrow court stated that it "need not consider the factual questions concerning the degree of participation by appellants in the settlement hearing and negotiations since the failure of appellants formally to intervene, after receipt of notice under [FRCP] 23(e) before final judgment forecloses their right to appeal."31 Three factors, however, indicate that the language in the body of the Asgrow opinion should control. First, the Asgrow appellees raised this point to show the appellants' acquiescence in the settlement; they did not argue they had met the court's appearance requirement. ${ }^{32}$ Second, the body of the text cites Cohen in support of its holding, ${ }^{33}$ and Cohen does not require intervention. Third, later cases in the Seventh Circuit have affirmed Asgrow and held that an objection be-

28 Id.

${ }^{26}$ Id, quoting Pianta $v$ H.M. Reich Co., 77 F2d 888, 890 (2d Cir 1935).

27 425 F2d 1059 (7th Cir 1970) ("Asgrow"). Note that while most courts refer to this case as "Asgrow," some others use "Research Corp."

29. Id at 1060.

29 Id at 1060-61 (citations omitted).

so See, for example, Croyden Associates v Alleco, Inc., 969 F2d 675, 679 (8th Cir 1992).

si Asgrow, $425 \mathrm{~F} 2 \mathrm{~d}$ at $1060 \mathrm{n} 2$.

s2 Id.

ss Id at 1060 . 
low is sufficient to confer standing on appeal. ${ }^{34}$ Since Cohen and Asgrow, the principle that an unnamed class member who has objected in the court below has standing to appeal an order approving a settlement has been well-established in the Sixth ${ }^{35}$ and Seventh Circuits, ${ }^{36}$ and indeed has become the most widely accepted solution to the question at hand. ${ }^{37}$

Nevertheless, the influence of this approach appears to be waning. In addition to the cases described in the next subsection, two recent Seventh Circuit decisions have cast a shadow on the Cohen/Asgrow approach. In Bash v Firstmark Standard Life, the court, denying a petition for rehearing, chastised the parties for failing to cite authority that would have dictated dismissing the appeal since the appellants had not intervened. ${ }^{38}$ And In the Matter of VMS Securities Litigation, the court adopted the reasoning of a line of cases that disagreed with Asgrow by holding that an unnamed class member could not appeal a post-settlement order issued pursuant to a settlement agreement. ${ }^{39}$ Although the court purported to "offer no opinion on the merit of [these principles] as applied to an unnamed class member who appeals the approval of a [settlement order]," it admitted to adopting the reasoning of these cases "to address the related issue of whether an unnamed class member can appeal a post-settlement order implementing the settlement agreement." ${ }^{\text {40 }}$

\footnotetext{
s4 Tryforos v Icarian Development Co., S.A., 518 F2d 1258, 1263 n 22 (7th Cir 1975); Armstrong $v$ Board of School Directors, 616 F2d 305, 327 (7th Cir 1980).

ss Sertic v Carpenters District Council, 459 F2d 579, 581 (6th Cir 1972); Steiner v Fruehauf Corp., 121 FRD 304, 307 (E D Mich 1988).

3e Tryforos, $518 \mathrm{~F} 2 \mathrm{~d}$ at $1263 \mathrm{n} 22$; Armstrong, $616 \mathrm{~F} 2 \mathrm{~d}$ at 327.

${ }^{37}$ See Greenfield $v$ Villager Industries, Inc., 483 F2d 824, 829 (3d Cir 1973); Tate $v$ Werner, 68 FRD 513, 519 (E D Pa 1975); Webcor Electronics v Whiting, 101 FRD 461, 465 n 11 (D Del 1984); Dosier v Miami Valley Broadcasting Corp., 656 F2d 1295, 1299 (9th Cir 1981); In re Cement Antitrust Litigation, 688 F2d 1297, 1309 (9th Cir 1982); Silber v Mabon, 957 F2d 697, 700 (9th Cir 1992); In re Four Seasons Securities Laws Litig., 502 F2d 834, 844 (10th Cir 1974); In re Dennis Greenman Securities Litig., 829 F2d 1539, 1542 (11th Cir 1987); Ackert v Ausman, 217 F Supp 934, 935-36 (S D NY 1963). See also Newberg, Class Actions \$ 1.08 at 14 (cited in note 1); Charles A. Wright, et al, 7B Federal Practice and Procedure $\$ 1797$ at 360-61 (West, 2d ed 1986); James W. Moore and John E. Kennedy, 3B Moore's Federal Practice II 23.80 at 496 (Matthew Bender, 2d ed 1992).

ss 861 F2d 159, 164 (7th Cir 1988).

s9 976 F2d 362 (7th Cir 1992).

$40 \mathrm{Id}$ at $368 \mathrm{n} 8$.
} 
C. Unnamed Class Members May Only Appeal If They Have Intervened Below

In 1987, the Eleventh Circuit sowed the seeds of a new approach in Guthrie $v$ Evans. ${ }^{41}$ The case involved a pro se appeal by a Georgia prison inmate who challenged a judgment on the merits (not a settlement) in a class action suit. ${ }^{42}$ The Guthrie court apparently found this distinction dispositive; it stated (despite the existence of cases like Cohen and Asgrow) that it could locate no precedent in any circuit on the issue of whether an unnamed class member could appeal such a judgment. ${ }^{43}$ The court then held that given the numerous other avenues of relief available to dissatisfied class members (intervention, a collateral attack on the adequacy of representation, and opting-out of the class), as well as the danger that individual appeals could render class actions "unwieldy," the appellant did not have standing.44

Walker $v$ City of Mesquite ${ }^{45}$ was the first case specifically to hold that unnamed class members do not have standing to appeal an order approving a settlement in a class action unless they have successfully intervened in the court below. Relying on Guthrie and Marino $v$ Ortiz, a Supreme Court decision holding non-parties should be required to intervene in order to appeal a judgment, ${ }^{46}$ the court concluded that a rule that did not require intervention by the unnamed party "would result in the frustration of the purpose behind class litigation." ${ }^{27}$ Presumably such a rule would cause a consolidation of claims to deteriorate into a myriad of individual disputes, each complete with its own appeal.

In Croyden Associates $v$ Alleco, Inc., the Eighth Circuit affirmed the reasoning in Walker and reiterated that case's reliance on Guthrie and Marino, concluding that "we see no decision that has pointed to a flaw in their analysis." 48 Croyden provides the most recent decision on this issue, and is the only decision that has explicitly weighed alternate approaches in deciding this question.

Walker and Croyden thus present an entirely new approach in what had been a much more limited debate over the procedural

41815 F2d 626 (11th Cir 1987).

12 Id at 627 .

43 Id.

44 Id at 628-29.

45858 F2d 1071, 1074 (5th Cir 1988).

16 484 US 301, 304 (1988).

$47858 \mathrm{~F} 2 \mathrm{~d}$ at 1074.

4. 969 F2d 675, 679-80 (8th Cir 1992). 
prerequisites for unnamed class members seeking to appeal settlement orders. Formerly, the concern was simply whether an objection in the court below would be required to confer standing on appeal. Now, unnamed class members face the possibility of a much different, and much more onerous, requirement: actual intervention. ${ }^{49}$

\section{An Evaluation of the Solutions: Three Perspectives}

This Section analyzes the three positions outlined above from three different perspectives. First, the positions are considered in light of their historical origins, with particular emphasis on the departure from traditional reasoning that has occurred within the last five years in this area. Next, the discussion focuses on the application of the equitable principles typically employed in analyzing class-action rules: the importance of appellate court review, as well as some of the individual equities presented in various situations. Finally, the analysis turns to the concerns of economy and efficiency and examines the incentives at work, as well as the practical results obtained, under each of the three rules.

\section{A. History}

Were it not for a few misinterpreted decisions, the question of whether an unnamed class member has standing to appeal an order approving a settlement would essentially be limited to whether or not the appellant should be required to have objected in the court below. Instead, there is now a third alternative, one requiring actual intervention in the court below. But this requirement has no historical foundation. And while this conclusion is far from the end of the matter, it serves as a useful groundwork for any consideration of the merits of the three alternatives.

Some 150 years ago, the English scholar Frederic Calvert argued that "the privilege of appeal [in class action suits] ought to be given in such a manner as to induce the readiest acquiescence in the system of representation during the earlier part of the suit; for which reason every individual ought, as it appears to me, to . . .

\footnotetext{
19 Presumably, the unnamed class member would move to intervene as "of right" under FRCP 24(a)(2). Note that a peculiar paradox arises when the standards for intervention and the scope of class action judgments are combined. "[T]he judgment in a class action will bind only those members of the class whose interests have been adequately represented by existing parties to the litigation; yet intervention as of right presupposes that an intervenor's interests are or may not be so represented." Sam Fox Publishing Co., Inc. v United States, 366 US 683, 691 (1961) (citations omitted).
} 
have the power of appealing, whether he has been a suitor ... or by some other person as his representative." And, "if the right of . . a person . . . in any way is bound by the decree, he must have a right to appeal from it, as well as the person against whom it was made." ${ }^{\text {"I }}$ Calvert traced this reasoning back to the eighteenth-century decision in Osborne $v$ Usher. ${ }^{52}$ In Osborne, the House of Lords specifically considered whether to allow an appeal by a party whose interest had been represented by another party below. The Lords allowed the appeal but upheld the decree. ${ }^{53}$ While the precedential value of Osborne is an issue for antiquarians, it does represent a long-standing appreciation of access to appellate review by persons whose rights and duties are being determined by the courts. ${ }^{54}$

Joseph Story reiterated these principles for Americans in his Commentaries on Equity Pleadings. ${ }^{55}$ Discussing suits where the parties were too numerous to appear before the court, Story stated, "they may come in under the decree, and take the benefit of it, or show it to be erroneous, or entitle themselves to a rehearing." Story and Calvert both evidence a long history of taking a liberal view of appeals by unnamed "class members." Even today, courts consistently recognize the fundamental rule that those "who demonstrate 'prejudice' from [a] settlement" must be granted standing to appeal. ${ }^{57}$ Whether these references point toward Ace Heating and Marshall or toward Cohen and Asgrow is debatable. Calvert and Story wrote in a context far removed from that of the

\footnotetext{
so Frederic Calvert, Observations on Suits in Equity 38 (William Benning, 2d ed 1846).

${ }^{51}$ Frederic Calvert, Parties to Suits in Equity 66 (William Benning, 2d ed 1847), quoting Giffard v Hort, 1 Schoales \& Lefroy 386, 409 (Irish Ct of Chancery 1803).

326 Brown's Parliamentary Cases 20 (1721).

ss Id at 26 .

st There is a link-albeit somewhat tortured-between Calvert's reasoning and that of the American courts. Calvert is cited in Blossom v Milwaukee \& Chicago R.R. Co., 68 US (1 Wall) 655,656 (1863), which allowed an appeal of a sale by a bidder at a foreclosure sale stating that parties may "acquire rights in regard to the subject-matter of the litigation, which the court is bound to protect." Id. Blossom is cited in Hinckley $v$ Gilman, 94 US 467 (1876). In Hinckley, a receiver, not a party to the action below, was "subjected to the jurisdiction of the court, and made liable to its orders and decrees. He [had], therefore, the corresponding right to contend against all claims made against him." Id at 469. Hinckley is cited in Christian v R. Hoe \& Co., 63 F2d 218, 218 (2d Cir 1933), which, in turn, is cited in Pianta v H.M. Reich Co., 77 F2d 888, 890 (2d Cir 1935). Finally, Cohen v Young quotes Pianta. 127 F2d at 724.

${ }^{6 s}$ (Little, Brown, 2d ed 1840).

so Id at 96.

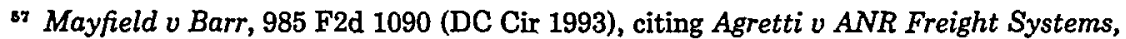
Inc., 982 F2d 242, 246 (7th Cir 1992).
} 
current procedural rules. It is sufficient to say that courts have traditionally made such appeals easily available.

Guthrie made an abrupt departure from this established background, but only in the context of an appeal from a final judgment. Several factors indicate that the court did not intend its holding to reach appeals of settlements. The court's failure to acknowledge cases such as Cohen and Asgrow suggests that the court recognized a significant distinction between an appeal from a final judgment and an appeal from a settlement order. ${ }^{58}$ Also, there is the ubiquitous presence of Judge Hill. The Guthrie panel was composed of

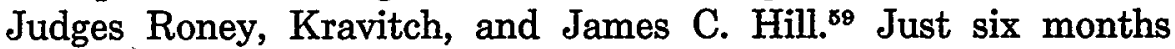
later, Judge Hill also sat on the panel that decided In re Dennis Greenman Securities Litigation. ${ }^{60}$ In Greenman, the court specifically addressed the appealability of settlements and cited Asgrow for the proposition that an unnamed class member who had objected to a settlement had standing to appeal an order approving that settlement. ${ }^{61}$ Greenman did not mention Guthrie at all. Moreover, the same Judge Hill also wrote the opinion in Cotton $v$ Hinton, which allowed an appeal by an unnamed class member without raising the issue of standing. ${ }^{62}$ The only reasonable conclusion one may derive from all of this is that Guthrie did not address the question of whether an unnamed class member has standing to appeal a settlement order in a class action.

Nevertheless, other courts have taken Guthrie to control the issue, thus creating an entirely new approach to unnamed class members' rights. For example, Walker made the mistake of applying Guthrie beyond its limits by relying on Guthrie in holding that an unnamed class member must intervene below to appeal a settlement. ${ }^{63}$ It then compounded the error by finding support in $\mathrm{Ma}$ rino $v$ Ortiz, where the Supreme Court held that non-parties should be required to intervene rather than undertake a direct appeal of a settlement. ${ }^{64}$ As discussed below, it is by no means neces-

${ }^{88}$ Guthrie, 815 F2d at 627 . There are, of course, two explanations for this: either the Guthrie court considered these cases inapplicable, or it simply failed to find them. Both of these reasons make reliance on Guthrie questionable.

so Id.

co 829 F2d 1539, 1540 (11th Cir 1987).

61 Id at 1542-43.

62 559 F2d 1326, 1329 (5th Cir 1977).

${ }^{63} 858$ F2d at 1073-74. Shores $v$ Sklar, 844 F2d 1485 (11th Cir 1988), vacated 855 F2d 722 (11th Cir 1988), partially reinstated, 885 F2d 760 (11th Cir 1989), had also made the mistake of applying Guthrie to settlement situations, though Shores itself involved the timing of an appeal from a motion to intervene. $844 \mathrm{~F} 2 \mathrm{~d}$ at 1491.

64 484 US 301, 304 (1988). 
sary, or even likely, that this reasoning should apply to unnamed class members. ${ }^{65}$ Most distressing in all of these decisions is the failure to give so much as a footnote to the numerous cases from other circuits holding to the contrary. For the Walker court to support its conclusion with a case that said an unnamed class member cannot appeal a judgment on the merits and another case holding that non-parties should be required to intervene before appealing might have been tenable were it not for ample persuasive authority to the contrary, but Walker reached a contrary result without so much as a citation to an established line of cases on point.

The most recent case on this issue, Croyden, mentions some conflicting authority, but does little more than scratch the surface before concluding that unnamed class members may not appeal a settlement order unless they have successfully intervened below. Croyden cites Asgrow but explains its holding by pointing to an inconsistency in a footnote ${ }^{66}$ Croyden failed to recognize that $A s$ grow was merely one of a rather extensive line of cases holding or implying a different solution than Walker ${ }^{67}$ Rather than address the arguments raised in this line of cases, the court chose to endorse Guthrie's a priori approach-as if faced with a simple policy choice between two equally legitimate rules. In essence Croyden failed to appreciate the subtleties of the argument; viewed in its proper historical context, Croyden is extremely shallow.

Courts that have yet to approach this issue, or courts that may wish to reconsider it, should realize that rather than being confronted with three more or less equally legitimate lines of cases, they in fact face a choice between two doctrines supported by a lengthy tradition and a third doctrine that rests on a clumsily reasoned line of inferences and unsubstantiated conclusions. Arguably, the debate that should be taking place is the one implicit in the pre-Guthrie cases: whether or not requiring an objection by an unnamed class member before allowing an appeal is desirable. Of course, the errors described above may be a blessing in disguise, and their conclusions deserve independent consideration. This evaluation takes place in the next two subsections. Suffice it to say that of the three options facing the courts today, the choices that place the least restriction on the ability of unnamed class members to appeal have the strongest historical foundation.

\footnotetext{
See text accompanying notes 76-80.

66 969 F2d at 679 n 5.

67 No mention is made, for instance, of any of the Sixth Circuit precedent.
} 


\section{B. Procedural Equity and Access to Appellate Review}

Surprisingly, the Supreme Court has never held that due process demands an opportunity for appellate review of a lower court's decision. ${ }^{68}$ Combined with the minimal due process requirement of "notice reasonably calculated, under all the circumstances, to apprise interested parties of the pendency of the action and afford them an opportunity to present their objections," ${ }^{\text {e日 }}$ it would seem that FRCP 23(e)'s notice and hearing requirements are all the Constitution demands. ${ }^{70}$

Federal law (28 USC § 1291), however, gives appellate jurisdiction to the courts of appeals from "all final decisions of the district courts," and it is firmly established that parties to a suit have an appeal of right from an adverse decision of the district court. ${ }^{71}$ In a non-class action proceeding, a settlement to which the parties have agreed will never give rise to an "adverse decision." 72 But in a class action there is a strong chance that a settlement to which the named parties have agreed will represent a sort of "adverse decision" to unnamed, non-negotiating parties. What procedural avenues should thus be open to the unnamed class members?

\section{Principles.}

Federal court.rulings in the context of other sorts of appeals suggest that unnamed parties should be permitted to appeal settle-

${ }^{68}$ See, for example, Lindsey $v$ Normet, 405 US 56, 77 (1982) ("This Court has recognized that if a full and fair trial on the merits is provided, the Due Process Clause of the Fourteenth Amendment does not require a State to provide appellate review."). See also Nat'l Union of Marine Cooks and Stewards v Arnold, 348 US 37, 43 (1954).

${ }^{6}$ Mullane $v$ Central Hanover Bank \& Trust Co., 339 US 306, 314 (1950).

70 This avoids the question of whether or not any given settlement proceeding, or even the realities of settlement proceedings in general, actually meet the demands of Mullane. However, any deficiencies in this regard could be challenged under Mullane. If a court determined that the notice in question was inadequate, challenging parties would then be allowed to "present their objections." Whether or not the unnamed class member could then appeal a settlement is the question this Comment addresses.

${ }^{71}$ Wright, 15A Federal Practice $\S 3902$ at 63 (cited in note 37). See also Robert J. Martineau, Modern Appellate Practice § 1.1 at 2 (Lawyers Co-operative, 1983). In the Fourteenth Amendment context, the Court has stated that "[w] hen an appeal is afforded ... it cannot be granted to some litigants and capriciously or arbitrarily denied to others without violating the Equal Protection Clause." Lindsey, 405 US at 77.

${ }_{72}$ "Parties who have consented to entry of a judgment at times are said to lack standing to appeal, and occasionally appeals from consent judgments are simply dismissed. The true principle at work, however, is one of waiver or consent; the appropriate disposition, if the appeal represents no more than a retroactive attempt to undo consent properly given, is affirmance rather than dismissal." Wright, 15A Federal Practice $\S 3902$ at 91-92 (cited in note 37). 
ments. The Supreme Court, in allowing non-parties to challenge orders approving settlements, has stated that a "judgment or decree among parties to a lawsuit resolves issues as among them, but it does not conclude the rights of strangers to those proceedings." While the Court recognized an "exception" for situations where the non-party is otherwise adequately represented, for example, in a class action, ${ }^{74}$ an appellate court will only review the substance of a judge's decision to approve a settlement if unnamed class members are allowed to appeal. This is also the only way an appellate court will ever review whether an unnamed class member has become a "stranger" for the purposes of settlement. To accept anything more restrictive than the Cohen/Asgrow approach to this issue would jeopardize unnamed class member rights, and undermine the very interests that the Federal Rules, the courts, and commentators have persistently sought to protect.

Lower court pronouncements on the question. of whether a non-party can appeal a class action settlement also support granting the right of appeal to unnamed class members. Numerous decisions, especially in the Second and Ninth Circuits, have allowed non-parties to appeal when their interests are at stake and the equities weigh in favor of hearing the case. ${ }^{75}$ Permitting appeals by strangers to the suit while maintaining a more restrictive rule for those who are already parties to the suit would be fundamentally inconsistent. Non-parties are allowed to appeal when they have no voice in proceedings that affect their rights. This is precisely the claim of unnamed parties-that they have lost their voice in proceedings that affect their rights. Accepting the Walker/Croyden approach thus not only rejects directly contrary cases, it calls other established decisions into question as well.

73 Martin v Wilks, 490 US 755, 762 (1989).

34 "We have recognized an exception to the general rule when, in certain limited circumstances, a person, although not a party, has his interests adequately represented by someone with the same interests who is a party." Id at $762 \mathrm{n} 2$, citing Hansberry $v$ Lee, 311 US $32,41-42$ (1940).

${ }_{73}$ See, for example, Hispanic Society v NYC Police Dept., 806 F2d 1147, 1152 (2d Cir 1986), affirmed as Marino v Ortiz, 484 US 301 (1988), discussing "exceptions" to the general rule that only parties may appeal. See also United States v Int'l Brotherhood of Teamsters, 931 F2d 177, 183-84 (2d Cir 1991), quoting Hispanic Society in support of allowing an appeal "when the nonparty has an interest that is affected by the trial court's judgment."

In the Ninth Circuit, SEC $v$ Wencke, 783 F2d 829, 834 (9th Cir 1986), held that nonparties may appeal where "they participated in the district court proceedings," and "the equities weigh in favor of hearing the appeal." See also Hal Roach Studios, Inc. v Richard Feiner and Co., Inc., 896 F2d 1542, 1546-47 (9th Cir 1990); EEOC v Pan American World Airways, Inc., 897 F2d 1499, 1504 (9th Cir 1990); Class Plaintiffs v City of Seattle, 955 F2d 1268, 1277-78 (9th Cir 1992). 
Perhaps, however, both non-parties and unnamed parties should not be allowed to appeal, but should be required to intervene instead, on the grounds that the action may "impair or impede" their ability to protect their interests, and their interests are not "adequately represented by existing parties." Indeed, the Supreme Court in Marino suggested such an approach: "We think the better practice is for such a non-party to seek intervention for purposes of appeal."77 Several factors, however, point toward a more permissive rule for unnamed parties. First, a subsequent court is less likely to find that a non-party's interests have been foreclosed by a decision in a case in which the party did not participate. Second, non-parties are more likely to intervene successfully since, unlike unnamed parties, they need not overcome a finding that their interests are adequately protected by class representatives. ${ }^{78}$ Third, lower courts have not taken Marino as proffering an unqualified command; they have decided that a nonparty may sometimes appeal without prior intervention..$^{79}$ Finally, the Marino Court noted that " $[t]$ he rule that only parties to a lawsuit, or those that properly become parties, may appeal an adverse judgment, is well settled."80 Inasmuch as unnamed parties are parties, as courts have traditionally considered them for purposes of appeal, requiring intervention seems unwarranted.

Appellate review offers important protection through the exercise of procedural checks over the actions of district courts. ${ }^{81}$ Class action settlements are supervised precisely because of the danger that unnamed class members' rights may be compromised in favor of the interests of the named representatives. In most cases that involve a review of district court discretion, the appellate courts can trust that there were advocates before the court arguing on behalf of the parties. Here, however, such protection is arguably absent; class members are necessarily somewhat at odds with the representative parties who have agreed to the settlement at issue. Whether or not this demands a formally heightened standard of

78 See FRCP 24(a).

77484 US at 304.

78 See FRCP 24(a) (permitting intervention by applicants whose interests would be adversely affected by the disposition of the action, "unless the applicant's interest is adequately represented by existing parties").

79 See Hal Roach Studios, 896 F2d at 1546-47; Pan American, 897 F2d at 1504; Class Plaintiffs, 955 F2d at 1277-78.

so 484 US at 304, citing United States ex rel Louisiana v Jack, 244 US 397, 402 (1917).

81 "It is the essential criterion of appellate jurisdiction, that it revises and corrects the proceedings in a cause ..." Marbury $v$ Madison, 5 US (1 Cranch) 49, 68 (1803). 
appellate review is another issue (the district court, of course, is still much more familiar with the facts and circumstances of the case and the situations of the litigants), but it at least heightens the need for relatively easy access to some sort of meaningful review. Class action litigation is often protracted, contentious, and complex. Settlements in such situations are understandably welcomed and encouraged by district court judges. Yet even the most conscientious and diligent judge may be tempted to overlook what are often eleventh hour objections to settlements in the absence of appellate review.

\section{Practice.}

To highlight some of these equitable concerns, one must examine the circumstances in which the appealability issue arises and consider how the courts have treated the litigants. Sympathetic litigants alone are an inadequate foundation for propounding legal rules, and the prospective effect of a harsher rule is admittedly less troubling if future parties will know the rules prior to their actions. Still, one cannot help feel that the courts that have required intervention as a prerequisite to appeals from class action settlements have done so with little or no regard for the equities involved.

Guthrie spawned the doctrine that unnamed class members must intervene in order to appeal an order approving a settlement. ${ }^{82}$ The background to Guthrie is sketchy at best-the opinion only refers to "thirteen years of litigation"- after which the district court "permanently enjoined the defendants from violating prior orders of the court." "8s The appellant, Keiter Parrot, an inmate at the Georgia State Prison, was unsatisfied with the resolution of certain discrimination claims filed on behalf of himself and other inmates. ${ }^{84}$ The court concluded that "if each class member could appeal individually, the litigation could become unwieldy. Thus, allowing direct appeals by individual class members who have not intervened in the district court would defeat the very purpose of class action lawsuits."85 One can appreciate the court's fear that every unnamed class member would seek to appeal the settlement order and create a whirlwind of fruitless and repetitive

\footnotetext{
See text accompanying notes 41-44.

815 F2d at 627.

See Guthrie v Evans, 93 FRD 390, 391-93 (S D Ga 1981). This is the only other reported opinion relating to this litigation.

815 F2d at 629.
} 
litigation. Yet it is hard to see how appeals by those who have intervened pose any less of a problem-dissenting parties' claims will still break off from the class action litigation. But the requirement does provide another procedural pitfall that will weed out the less sophisticated. In Guthrie, for instance, a prison inmate, proceeding pro se ${ }^{86}$ could not convince the court that his appeal should be heard. The result might have been quite different if the appellant had been able, say, to at least force a discussion of the Cohen/ Asgrow line of cases.

Guthrie, of course, does not purport to address appeals of orders approving settlements. ${ }^{87}$ No such saving distinction can be found for Walker. The facts behind this case again demonstrate the difficulties that arise when less sophisticated litigants are involved. Eight named plaintiffs settled a class action suit against, among others, HUD and the Dallas Housing Authority. ${ }^{88}$ Two unnamed class members raised objections at the settlement hearing, and after the court approved the settlement, the unnamed class members moved to intervene and challenge the court's decree. ${ }^{89}$ The district court denied their motion and the class members appealed. Unfortunately, they made the mistake of appealing the settlement rather than the denial of their motion to intervene. ${ }^{90}$ This allowed the court to seize on Guthrie to dispose of the appeal-effectively foreclosing on any appellate review of the district court's decision to approve the settlement. Again, pro se litigants were apparently too much of a gadfly for the court's docket, and one cannot help but see the judges reaching for a procedural excuse to avoid dealing with the merits of their claims. ${ }^{91}$

Croyden also strikes a somewhat jarring chord to the ear of equity. In this case, a charitable foundation appealed a settlement negotiated between a group of debenture holders and their issuer after having "submitted written objections to the fairness of the settlement, appeared at the [settlement] hearing, and made oral objections to the proposed settlement." ${ }^{\text {"92 }}$ The appellants took an

${ }^{86}$ Id at 627.

${ }^{87}$ See text accompanying notes 58-62.

88 858 F2d at 1072-73.

${ }^{89} \mathrm{Id}$.

90 Id at 1073.

91 How can the Walker appellants be faulted-and their appeal dismissed-after participating in the process to a degree which, under any standard current at the time, would protect their rights to appeal? See also Note, Walker v. City of Mesquite: The Nonappealability of Class Action Consent Decrees by Nonnamed Class Members, 63 Tulane L Rev 1732 (1989).

92969 F2d at 677 . 
obvious interest and role in the proceedings throughout. They certainly would have moved to intervene had they thought it necessary. There is no indication that such a motion would have saved the courts any work, assuming that the motion for intervention would have been denied and appealed. To preclude access to appellate review where the appellant has failed to intervene thus unduly burdens both the court system and the objecting party. In short, Croyden, like Walker, violates principled access to appellate review, without providing any substantial benefit.

\section{Judicial Efficiency}

Equitable principles are of little use, however, if by their very operation they exhaust the limited resources of the courts so as to inhibit adjudications in other cases. If there were no costs involved and if resources were infinite, there would be little need for class actions at all, let alone class action settlements. But given costs and scarcity, one might agree with all the arguments set out above, and still conclude that an intervention requirement may be necessary in order to encourage active participation in settlement proceedings and limit the number of unnecessary appeals. When one considers the incentives of all the parties involved, however, the Cohen/Asgrow approach seems to serve best the interests of efficiency.

\section{Incentives for the parties.}

The driving purpose behind the class action lawsuit is to uniformly adjudicate the similar claims of parties where individual suits would be impractical. ${ }^{93}$ If an action is properly certified as a class action by the district court, one may assume that this certification represents a choice of a more efficient means of settling the dispute. Thus, class actions in general should be encouraged insofar as they represent a less costly way to bring claims before the courts.

\footnotetext{
${ }^{93}$ A class may be certified under FRCP 23(b)(1), (2), or (3). While the various types of class actions address different situations, all share a common concern for rendering otherwise unmanageable litigation practical. Rule $23(\mathrm{~b})(1)$ purports to accommodate "[t]he diffculties which would be likely to arise if resort were had to separate actions by or against the individual members of the class . . ." FRCP 23 Advisory Committee Note (1966). Rule 23(b)(2) provides for cases where a class might comprise "members [who] are incapable of specific enumeration." Id. Rule 23(b)(3) "encompasses those cases in which a class action would achieve economies of time, effort, and expense, and promote uniformity of decision as to persons similarly situated, without sacrificing procedural fairness or bringing about other undesirable results." Id.
} 
In general, settlement between the parties in any litigation will occur when the settlement represents a more efficient resolution of the dispute relative to the net costs of adjudication by the court.94 Each party is generally free to assess costs and benefits and bargain with each other party, which is not the case where the result is dictated by a judge or jury. ${ }^{85}$ "[F] acilitating the settlement of [a] case" is an acknowledged goal of the federal courts, ${ }^{98}$ and it is no surprise that courts have applied this reasoning to class actions. ${ }^{97}$ Assuming proper certification and settlement proceedings in the district courts, one may conclude as a general matter that: 1) class actions are preferable to disaggregated individual suits, and 2) settled class actions are preferable to fully litigated class actions.

How, then, do each of the three approaches to allowing appeals by unnamed class members affect class actions in general, and settlement of those actions in particular? Class action suits require representative parties willing to prosecute them and unnamed class members willing to participate in them..$^{98}$ Representatives will be encouraged to go forward with claims the greater the probability that they will be able to settle their cases unhampered by the appeals of unnamed class members. Conversely, class members will be encouraged to participate in actions the greater the probability that they will be able to appeal a settlement that they oppose.

The Cohen/Asgrow approach has the distinction of balancing the interests of both named and unnamed parties rather than promoting the interests of one at the expense of the other. This ap-

94 See Frank H. Easterbrook, Justice and Contract in Consent Judgments, $1987 \mathrm{U}$ Chi Legal F 19 n 1.

${ }^{95}$ Of course, the instant issue arises precisely because unnamed class members are not present to negotiate and agree to a settlement in the same manner that parties to non-class litigation necessarily are. But assuming a fair settlement with adequate procedural safeguards - that is, an equitable solution to the present issue-a settlement is generally a more efficient resolution of a dispute.

${ }^{28}$ FRCP 16(a)(5).

97 "[There is an] interest in encouraging settlements, particularly in class actions, which are often complex, drawn out proceedings demanding a large share of finite judicial resources." Mayfield v Barr, 985 F2d 1090 (DC Cir 1993). "Particularly in class action suits, there is an overriding public interest in favor of settlement." Cotton $v$ Hinton, 559 F2d 1326, 1331 (5th Cir 1977).

\$8 "Participate" in this context does not mean playing an active role in court proceedings, but agreeing to be represented by the named parties. There is of course no required "agreement" between class representatives and other class members, but a number of procedural devices effectively act to express opposition to the actions of the representatives. Instituting or maintaining separate actions, opting-out of the class, and collaterally attacking the adequacy of representation, for example, all serve to undermine the viability of a class representative's actions. 
proach gives class representatives a certain amount of repose in that they need only concern themselves with objections raised at the settlement hearing. Likewise, dissatisfied class members can take comfort in the knowledge that they need only object before the court below in order to secure an opportunity to be heard on appeal.

By contrast, the Ace Heating/Marshall approach would make class actions even more appealing to unnamed class members, since it gives them even more leeway in advancing their concerns; at the same time, this approach reduces incentives for representatives. On the other hand, the Walker/Croyden approach would encourage representatives to undertake suits, but it would discourage participation by unnamed class members. Since a successful class action suit, that is, one that fairly and adequately presents the claims of the class, demands that both the class representatives and the unnamed class members "participate," the Cohen/Asgrow approach will likely result in the greatest number of appropriate class actions-since there will be more cases in which each group's risk is at an acceptable level.

As for the settlement itself, the incentives are oriented slightly differently. Once the class action is under way, any rule that restricts the ability of unnamed class members to appeal will increase the probability that the class representatives will be able to settle the case. The Walker/Croyden approach would thus produce the most settlements and the Ace Heating/Marshall approach the fewest.

However, at this stage of the analysis, the purpose of the procedural rules changes slightly. In assessing incentives to initiate a class action, we assumed proper certification proceedings. This is a relatively harmless presumption given that the named plaintiffs and defendants will usually dispute the propriety of certification, giving the court a great deal of information with which to work. The parallel assumption here, though, would be to assume fair settlement proceedings. But this entire inquiry seeks to explore options for class members who feel the settlement is unfair. Thus, properly-focused settlement incentives seek not only to encourage a greater number of settlements by allowing the class representatives a freer rein, but also act to check any tendency to settle unfairly. Again, the rule that encourages settlement to a reasonable degree, and also encourages fair settlements by allowing unnamed 
parties to challenge the settlement effectively, is the Cohen/Asgrow approach. ${ }^{99}$

2. Productive use of the courts.

On a less abstract level, one must consider which approach to the present issue makes the best use of the limited resources of the courts. One can best appreciate the competing concerns and options involved in an approach so intimately connected to the nuts and bolts of procedure by following a hypothetical case through each of the stated approaches.

Assume an unnamed class member, call him U, receives notice of a proposed settlement pursuant to FRCP 23(e), and further assume that $U$ is opposed to the settlement. If the case arises in a jurisdiction that follows the Cohen/Asgrow approach, U must take what the courts have called a "minimal" step to preserve the right to appeal a possible approval of the settlement: he must present his objections to the district court. ${ }^{100}$ This presentation can be as simple as sending a letter to the judge outlining U's concerns. ${ }^{101}$ The named class representative, call her $R$, is thus put on notice that U objects, and thus she can address U's concerns before the district court judge. The judge, though under obligation to consider all objections, ${ }^{102}$ has no duty to satisfy every class member. ${ }^{103}$ Her task is only to decide whether the settlement is fair and reasonable. ${ }^{104}$ If the district court judge approves a settlement to which $U$ still objects, $U$ may file an appeal challenging the order approving the settlement.

The appellate court will then review the district court judge's order for an abuse of discretion. ${ }^{105}$ If the court of appeals affirms the order, $U$ has exhausted his appeal of right, but only after a full and fair consideration of the merits of his objections before two courts. If the court of appeals vacates the order and remands the case back to the district court, the matter is essentially thrown back into the hands of $R$ and her adversary, call him $A$; for the court cannot propose a settlement, but can only approve a settle-

\footnotetext{
98 "Assuring fair and adequate settlements outweighs concerns that non-intervening objectors will render the representative litigation 'unwieldy.' "Bell Atlantic Corp. $v$ Bolger, 2 F3d 1304, 1310 (3d Cir 1993).

${ }^{100}$ Asgrow, 425 F2d at 1061.

101 See, for example, Weinberger v Kendrick, 698 F2d 61, 69 n 10 (2d Cir 1982).

102 See Bass v FSLIC, 698 F2d 328, 330 (7th Cir 1983).

${ }^{103}$ See Kincade v General Tire and Rubber Co., 635 F2d 501, 507-08 (5th Cir 1981).

$104 \mathrm{Id}$.

- ${ }^{108}$ See Donovan v Robbins, 752 F2d 1170, 1177 (7th Cir 1985).
} 
ment agreed upon by the parties. ${ }^{106}$ Then, either the litigation will go forward, or the parties will propose a revised settlement that will accommodate U's concerns. Though seemingly complex, when compared to the other two approaches, this solution emerges as relatively straightforward and economical.

In Ace Heating/Marshall jurisdictions, a few other possible paths lead to the same outcome-but these paths all make less efficient use of the courts' time. When $U$ gets a notice of a proposed settlement, he may still object in the district court, but he may also choose to wait and voice his concerns through an appeal. ${ }^{107}$ This rule protects $U$ against his own inadvertence (forgetting to file his objections with the district court) but also opens possibilities for strategic behavior ( $U$ may feel that the district court judge will be unsympathetic to his claim).

Appellate proceedings are different under Ace Heating/Marshall in two important respects. First, $R$ and $A$ have not had the opportunity to consider U's objections before agreeing to their settlement-eliminating the chance that $\mathrm{U}, \mathrm{R}$, and A could have solved this problem themselves. Second, the appellate court is placed in the difficult position of reviewing the district court's discretion with respect to U's objection, when the lower court has never heard the objections. It is thus highly likely that the appellate court will simply remand the case for reconsideration by the district court in light of U's objections. ${ }^{108}$ Thus, after an entry of an order and an appeal, U, R, A, and the courts are likely to be precisely in the same position had $U$ presented his objections at the settlement hearing-hardly a more productive use of the courts' or the parties' time.

The proceedings also differ if the case is brought in a Walker/ Croyden jurisdiction. When $U$ receives a notice of proposed settlement, he may of course appear at the settlement hearing, and the district court is still under obligation to consider his objections. ${ }^{109}$ But to preserve his right to appeal an order approving the settlement, $\mathrm{U}$ must move to intervene in the action. ${ }^{110}$ If the court approves the motion, $U$ takes on the status of a named party, but he is not necessarily any better off when it comes to challenging a pro-

108 See Cotton, 559 F2d at 1331-32.

107 See, for example, Ace Heating, 453 F2d at 32-33.

${ }^{108}$ See, for example, Greenfield v Villager Industries, Inc., 483 F2d 824, 834 (3d Cir 1973).

109 See Kincade, 635 F2d at 507; Cotton, 559 F2d at 1331.

110 Walker, 858 F2d at 1074. 
posed settlement in the district court. His assent is not necessary to the approval of the settlement. ${ }^{111}$ If the court denies the motion, $U$ may appeal that denial. ${ }^{112}$ If the court of appeals allows $U$ to intervene, he then acquires named party status, but, once again, he is not necessarily any better off with respect to the settlement. The Walker/Croyden approach produces more work for the district court (a formal motion in addition to the settlement hearing), no savings of time for the appellate court (in both cases it has conducted an appeal), and results in no review of the much more basic issue (the fairness and reasonableness of the settlement) by either court. In the end, it is somewhat circular to require objecting class members to intervene before they may appeal, since the only practical effect of intervention seems to be to allow standing on appeal. ${ }^{113}$

\section{The Guthrie "options."}

In spite of the reasoning outlined above, efficiency is the central argument advanced by the courts that adopt the Walker/ Croyden approach. ${ }^{114}$ These courts put forth three options that were first laid out in Guthrie: intervention, opting out of the class, and a collateral attack on representation.115 However, as noted above, intervention only allows an unnamed party to meet the courts' formal requirements for standing on appeal: it does not necessarily give any additional power over the settlement. ${ }^{136}$ Intervention can also wreak havoc with a suit in other ways-the proper

11 "[W]hile an intervenor is entitled to present evidence and have its objections heard at the hearings on whether to approve a consent decree, it does not have power to block the decree merely by withholding its consent." Firefighters $v$ City of Cleveland, 478 US 501, 529 (1986). "[T]he assent of named plaintiffs is not a prerequisite to the approval of a settlement." Kincade, 635 F2d at 508, quoting Pettway v American Cast Iron Pipe Co., 576 F2d 1157, 1216 (5th Cir 1978). See also County of Suffolk v Long Island Lighting Co., $710 \mathrm{~F}$ Supp 1428, 1434-35 (E D NY 1989).

112 Although denials of motions to intervene "are, of course, appealable," Marino $v$ Ortiz, 484 US 301, 304 (1988), some circuits review denials of motions to intervene de novo and some review for an abuse of discretion. See Sierra Club v Robertson, 960 F2d 83, 85 (8th Cir 1992) (collecting cases). To complicate matters even further, the timing involved in making and appealing such motions can be incredibly complex. Compare, for example, Shores $v$ Sklar, 844 F2d 1485, 1491 (11th Cir 1988), with United Airlines, Inc. v McDonald, 432 US $385,391-94$ (1977).

11 See, for example, Loran v Furr's/Bishop's, Inc., 988 F2d 554 (5th Cir 1993).

114 See Croyden, 969 F2d at 680.

11 Guthrie, 815 F2d at 628; Croyden, 969 F2d at 678; Walker, 858 F2d at 1073-74.

${ }^{118}$ See note 111. 
timing and appealability of such motions are complex, and in some cases may even defeat a federal court's jurisdiction. ${ }^{117}$

Opting out of a class is simply not an option for classes certified under FRCP 23(b)(1) or 23(b)(2), and even when possible under 23(b)(3), the result-more individual suits-is precisely what class action litigation seeks to avoid. It seems somewhat odd to deny standing on appeal in order to "channel into one line of the litigation all issues of the class action settlement"118 and then to point to the availability of separate suits as a justification. Moreover, in many cases, the option to opt out is no real option, but rather represents an all-or-nothing choice of entering a class action claim or making no claim at all. ${ }^{119}$

A collateral attack on the adequacy of representation similarly proves an illusory alternative. The burden of proving inadequate representation is much higher than necessary for what is, in fact, a challenge to a settlement; such an attack can only be successful if the claimants prove collusion, adverse interests, or nonfeasance. ${ }^{120}$ Moreover, the objector is likely to be caught in a shell game of alternate remedies. ${ }^{121}$ Once again, actual challenges to the merits of a settlement are swept out of the way in favor of preparing procedural pitfalls for the unwary.

\section{CoNCLUSION}

Courts should hold that unnamed class members have standing to appeal an order approving a settlement, provided the appel-

${ }^{117}$ Apparently, this was the case in Croyden. In their petition for certiorari, the Croyden appellants presented the question of whether an "appeal by [an] unnamed class member, whose intervention in an action under 28 USC 1332 is precluded by 28 USC 1367(b) because [the] class member's intervention would have destroyed 'complete diversity,' [may] be dismissed for lack of standing because the class member did not move to intervene." Weinberg Foundation, Inc. v Croyden Associates, 61 USLW 3372, No 92-613 (November 17, 1992).

118 Croyden, 969 F2d at 680.

118 "Rule 23 recognizes the fact that many small claimants frequently have no litigable claims unless aggregated. So, without court approval and a subsequent right to ask for review, such claimants would be faced with equally unpalatable alternatives-accept either nothing at all or a possibly unfair settlement." Ace Heating, $453 \mathrm{~F} 2 \mathrm{~d}$ at 33 . Tex 1991).

${ }^{120}$ See, for example, United States $v$ Texas Education Agency, 138 FRD 503, 514 (N D

122 "A class member who claims that his representation does not adequately represent him, and is able to establish that proposition with sufficient probability, should not be put to the risk of having a judgment entered in the action that, by its terms, extends to him, and be obligated to test the validity of the judgment as applied to his interest by a later collateral attack. Rather, he should as a general rule, be entitled to intervene in the action." Shump v Balka, 574 F2d 1341, 1344-45 (10th Cir 1978) (citations omitted). 
lants have presented their objections to the court below. This rule requires meaningful involvement as a prerequisite to appeal without violating the dictates of due process; it is the one solution to this problem that satisfies the demands of history, equity, and efficiency. Requiring intervention by unnamed class members is not only inequitable, it is less efficient and focuses on procedural niceties at the expense of considering the merits of the claims of unnamed class members. Conversely, allowing appeals unconditionally fails to appreciate the need for practical incentives in the settlement process. Ideally, procedural rules should make adjudications easier, fairer, and cheaper. Often these three factors compete for primacy, but when they are unanimous in their conclusion, their dictates must be endorsed. 